Corrigendum

\title{
FORGETTING APARTHEID: HISTORY, CULTURE AND THE BODY OF A NUN - CORRIGENDUM
}

\author{
Leslie J. Bank and Benedict Carton
}

doi: 10.1017/S0001972016000346, published in Africa, Volume 86, Number 3, pp. 472-503, 2016.

The authors wish to correct and explain spelling differences of some names in the above article. The East London Assistant Magistrate in November 1952 was $\mathrm{Mr}$ Snyman, not Mr Synman (487). The name Rheinhallt is missing one '1' (fn15, 476). Dr Sacks, the son of Lithuanian immigrants and a District Surgeon, was incorrectly spelled Dr Sachs. The authors mistakenly believed that Dr Sacks, the forensic pathologist, was related to another Lithuanian family in South Africa known by the last name of Sachs. Albie Sachs, a young anti-apartheid activist in the Defiance Campaign, came from this Sachs family. Today, he is an icon of the liberation struggle. The full name of a murder witness is given as Mavis Mkonebi. In oral testimony she is described simply as Mavis; some journalists in 1953 recorded her surname as Mkonebi $(487,488)$. Her sworn statements in archived court documents list Mavis' surname as Mkobeni. The correct legal name is Mkobeni. The last name of another trial witness, Ethel Dlabantu, sometimes appears in historical documents as Dhlabantu or Dhlarantu. We used Dlabantu because it was the most common spelling of Ethel's surname in the legal record (488). The surname of the murder witness, Ivy Plaatjies, was spelled Plaatjie in the Daily Dispatch. The Dispatch article referring to Plaatjie spells her surname without an 's' (fn 64, 487). Our article text refers to Plaatjies because it was the most common spelling of Ivy's surname in the historical record (488). The African National Congress Youth League leader Joel Lengisi was also known as Joel Lingisi. The authors are grateful to the editors of Africa for publishing this corrigendum. We take full responsibility for the typos and errors.

\section{REFERENCE}

Bank, L.J. and Carton, B. (2016) 'Forgetting apartheid: history, culture and the body of a nun', Africa, 86, pp. 472-503. 